\title{
Utilization of Radiation Therapy and Predictors of Noncompliance among Syrian Refugees in Turkey
}

\section{Mutlay Sayan ( $\square$ msayan@bwh.harvard.edu )}

Harvard Medical School https://orcid.org/0000-0002-0101-0951

Mehmet Fuat Eren

Marmara Üniversitesi: Marmara Universitesi

Sarah Sabrine Kilic

Cleveland Clinic

Ayse Kotek

Dr Ersin Arslan EAH: Dr Ersin Arslan Egitim ve Arastirma Hastanesi

Sedenay Oskeroglu Kaplan

Sanliurfa Egitim ve Arastirma Hastanesi

Ozge Duran

Sanliurfa Egitim ve Arastirma Hastanesi

Funda Cukurcayır

Balikesir Üniversitesi Tip Fakültesi: Balikesir Universitesi Tip Fakultesi

Ibrahim Babalıoglu

Konya Training and Research Hospital: Konya Meram Devlet Hastanesi

Ozlem Derinalp Or

Adana Numune Training and Research Hospital: Adana Numune Egitim ve Arastirma Hastanesi

Gul Aysen Ozturk

Bursa Training and Research Hospital: Bursa Yuksek Ihtisas Egitim ve Arastirma Hastanesi

Celalettin Eroglu

Erciyes Üniversitesi: Erciyes Universitesi

\section{Fatma Teke}

Dicle Universitesi

Neslihan Kurtul

Sutcu Imam University: Kahramanmaras Sutcu Imam Universitesi

\section{Tugce Kutuk}

Malatya EAH: Malatya Egitim ve Arastirma Hastanesi

Beyhan Ceylaner Bicakci

Istanbul Dr Lufti Kirdar Kartal Egitim ve Arastirma Hastanesi

\section{Sukran Senyurek}

Kahramanmaras Sutcu Imam University: Kahramanmaras Sutcu Imam Universitesi 
Necmettin Erbakan Üniversitesi Meram Tıp Fakültesi: Necmettin Erbakan Universitesi Meram Tip Fakultesi

\section{Swati Mamidanna}

Rutgers Cancer Institute of New Jersey

Nisha Ohri

Rutgers Cancer Institute of New Jersey

\section{Bruce Haffty}

Rutgers Cancer Institute of New Jersey

\section{Banu Atalar}

Acibadem Mehmet Ali Aydinlar University: Acibadem Universitesi

\section{Research Article}

\section{Keywords:}

Posted Date: April 5th, 2022

DOI: https://doi.org/10.21203/rs.3.rs-900501/v2

License: (1) (1) This work is licensed under a Creative Commons Attribution 4.0 International License. Read Full License 


\section{Abstract}

\section{Background}

Access to cancer care is a problem that continues to plague refugees displaced from their home countries. The turbulent political crisis in Syria, which has led to millions of refugees seeking asylum in Turkey, merits further attention. We aimed to study the rate of utilization of radiation therapy among Syrian refugees with cancer living in Turkey in an attempt to identify the contributing factors predictive of non-compliance with prescribed RT.

\section{Methods}

In this retrospective review of 14 institutional databases, Syrian refugee patients in Turkey with a cancer diagnosis from January 2015 to December 2019 who were treated with RT were identified. The demographic data, treatment compliance rates, and toxicity outcomes in these patients were surveyed. Variable predictors of noncompliance such as age, gender, diagnosis, , treatment length, and toxicity were studied. The association between these variables and patient noncompliance was determined.

\section{Results}

We identified 10,537 patients who were diagnosed with cancer during the study period, of whom 1010 (9.6\%) patients were treated with RT. Breast cancer (30\%) and lung cancer (14\%) were the most common diagnoses with up to $68 \%$ of patients diagnosed at an advanced stage (Stage III, IV). $20 \%$ of the patients were deemed noncompliant. Treatment with concurrent chemoradiotherapy (OR 1.61, 95\% Cl $1.06-2.46$, $p=0.023)$ and living in a refugee camp $(\mathrm{OR} 3.62,95 \% \mathrm{Cl} 2.43-5.19, \mathrm{p}<0.001)$ were associated with noncompliance. Age, gender and treatment length were not significantly associated with noncompliance.

\section{Conclusions}

Noncompliance with radiotherapy among Syrian refugees in Turkey remains an area of concern with a multitude of factors contributing to these alarming numbers. Further studies to better ascertain the finer nuances of this intricately complex problem and a global combination of efforts can pave the way to providing a solution.

\section{Introduction}

As political unrest continues to rage in the Middle East, Syria is still in a state of an ongoing, turbulent Civil War since its onset in 2011. After years of fighting against unjust oppression, millions of refugees have fled from the country to escape from the harsh circumstances that have been inflicted upon them, in search of a better way of life. Of the approximately 5.6 million people who have been displaced to the neighboring countries, Turkey is currently hosting the largest number of registered refugees, far more than any other country (1). Sharing a large common land border with Syria, making it accessible to this new 
population influx, Turkey has stepped forward during this critical time to provide shelter to almost 3.6 million of these troubled people, with the numbers only increasing with time.

This inadvertent migration allowed for an escape from the war but has however presented the refugees with a different set of challenges as they struggle to adapt to their new homes. One of the major concerns has been the influence on healthcare, particularly cancer care. Access to health care is enshrined as a human right in the Turkish Constitution and staying true to this principle, in April 2013, Turkey has passed its first law on asylum-the "Law on Foreigners and International Protection". This new set of regulations authorized the provision of free medical treatment to registered refugees in the manner generally provided to Turkish citizens, including cancer treatment and care at tertiary government and university hospitals (24).

Despite these amendments to facilitate the migrant population, an inconsistency between the healthcare services provided and services availed has been observed, primarily arising from the fact that this population has traveled far from their homeland to settle in new places, instigating multiple adjustment complexities (5). The particular stressors of war play a large role in their struggles, but additionally, this population of refugees often face challenges typical to new migrants such as marginalization, acculturation problems, socioeconomic disadvantages and 'cultural bereavement' $(6,7)$, which all negatively impact their overall wellbeing. There are numerous practical obstacles to maintaining good health as well, such as a lack of transportation, choice of health institutions, poor nutrition, unstable and unsafe living conditions, language problems, lack of education, economic inadequacy, and a lack of social security (8).

Numerous studies have been conducted on various healthcare outcomes in the refugee population, yielding a traditional health response focused on the provision of services that predominantly address communicable diseases (9). Other dominant areas of medical services distribution included treating cardiovascular diseases, hypertension or diseases with severe and immediate consequences owing to an interruption in management such as provision of insulin for type 1 diabetics or dialysis for kidney disease $(10,11)$. Cancer care, unfortunately, remains an acutely neglected part of the refugee health response and is an under-analyzed issue as only a limited number of studies address this subject. In this study, we have set out to evaluate the rate of radiation therapy utilization among Syrian refugees with cancer living in Turkey and identify the contributing factors predictive of non-compliance with prescribed radiation therapy (RT).

\section{Materials And Methods}

We performed a retrospective review of 14 Turkish institutional databases to identify Syrian refugee patients in Turkey with a cancer diagnosis from January 2015 to December 2019. Institutions were selected based on location within provincial regions known to host the highest numbers of Syrian refugees per United Nations High Commissioner for Refugees data (12). All institutions were members of the Turkish Radiation Oncology Society (Türk Radyasyon Onkolojisi Derneği). We then identified those 
patients treated with RT and surveyed the demographic data, toxicity outcomes, and treatment compliance rates. We included patients who underwent external beam RT and/or brachytherapy. Patients who were treated with palliative intent were also included. Patients younger than 18 years old were excluded. Early toxicity outcomes were graded by the treating physician during the treatment course using the National Cancer Institute Common Terminology Criteria for Adverse Events (CTCAE), version 3.0.

Patient compliance with prescribed radiation treatments was scored as a binary variable. All radiation treatments were once-daily. Patients who missed 2 or more scheduled RT appointments were deemed "noncompliant." Scheduled treatments that were cancelled because of issues related to the machine or physician-ordered planned treatment breaks did not count toward patient noncompliance. Follow-up was defined as the period from the time of completion of radiation therapy. Multiple variables that were tested as predictors on noncompliance included patient age, gender, diagnosis, residence of the patients, history of surgery, receipt of concurrent chemoradiotherapy, treatment length, and an acute toxicity of Grade $\geq 3$. Pearson's chi-squared test was used to determine the statistically significant differences in patients' subgroups defined by these variables. Univariate and multivariate logistic regression analyses were also performed to test for an association between patient noncompliance and the variables listed above.

Statistical analyses were performed using SPSS statistical software version 25 (IBM Corp., Armonk, NY, USA). A p-value less than 0.05 was considered statistically significant. This study was approved by the Institutional Review Board of Marmara University Pendik Research and Education Hospital (IRB 09.2019.615) and of every participating center.

\section{Results}

We identified 10,537 refugee patients who were diagnosed with cancer during the study period. Refugee status was verified by the national refugee billing ID code associated with each patient's treatment. A total of $1010(9.6 \%)$ of these patients were treated with RT. Patient characteristics are summarized in Table 1. Median age at the time of RT initiation was 49 (range, $19-94$ ), and $53 \%$ of patients were female. The most common diagnoses were breast cancer (30\%) and lung cancer (14\%). The majority of patients were diagnosed at an advanced stage (68\% Stage III-IV). Forty-four percent of patients were living in a refugee camp and $56 \%$ in a house. Grade $\geq 3$ acute toxicity was reported in $14 \%$ of the patients. Median follow-up was 6 months (range, $0-46$ months).

In total, $20 \%$ of patients were deemed noncompliant based on the definition of two or more missed RT treatments. Rates of noncompliance in patient subgroups are shown in Table 2. There was no significant difference in RT course length in noncompliant patients compared to those who were compliant (mean number of RT fractions, 19.7 vs 19.8, $\mathrm{P}=0.933$ ). All treatments were completed on an outpatient basis.

Bivariate and multivariable logistic regression results for associations with patient noncompliance are summarized in Table 3. Treatment with concurrent chemoradiotherapy was associated with noncompliance on multivariate analysis (odds ratio [OR] 1.61, 95\% confidence interval [Cl] $1.06-2.46, \mathrm{P}$ 
$=0.023)$. Living in a refugee camp was also associated with increased noncompliance (OR $3.62,95 \% \mathrm{Cl}$ $2.43-5.19, \mathrm{P}<.001)$. Treatment length was not associated with RT compliance.

\section{Discussion}

Radiotherapy is an evolving yet inseparable element in the realm of cancer management. It has a myriad of applications which include being a definitive curative option, in slowing cancer growth or as a palliative modality. Several studies have emphasized this importance of RT, showing that on an average more than half of all cancer patients require RT administration at least once during the course of their treatment $(13,14)$. In view of this, every patient should be able to have access to this beneficial modality of treatment. However, as we review data from around the world, there is a glaring disparity in the availability of RT services, which contrasts significantly between high-income countries when compared to middle to low-income countries. To further broadly analyze this area of concern, a study done in 2013 demonstrated high income countries such as the United States to have an estimate of 5075 RT departments with a total of 8911 megavoltage machines. This significantly differs from the middle to low income countries which range between having from 590 to as low as 40 RT departments with only 601000 machines (15).

Studies focusing on the availability of RT in Europe have demonstrated that almost three out of four cancer patients who have an evidence-based indication for RT have access to it $(16,17)$. In a stark contrast to this, low income countries in sub-Saharan Africa have an almost-complete absence of RT facilities $(18,19)$. To specifically focus on the situation of RT in Turkey, in 2012 there were 95 radiotherapy centers with 201 megavoltage equipment treating 160,808 patients with expected $44 \%$ unmet need (20). Even though there has been a definite increase in the development in the field of RT in Turkey over the past few decades, these resources are not sufficient to meet the demands of the everincreasing burden of patients diagnosed with cancer each year who require these facilities $(21,22)$.

There are a number of possible reasons as to why we observe this disproportionate chasm between the high-income and low-income countries. To establish RT centers equipped with megavoltage machines, the country's income classification plays a major role. A majority of the lower income countries still to this day struggle to provide RT services as they deal with the crippling issues of poverty and political instability, pushing services like radiation further down the list of things deemed crucial $(23,24)$. Aside from this, other factors such as the availability of electricity and the presence of highly qualified trained personnel to oversee the particulars of treatment delivery also play a crucial part in contributing to the underservices of RT (15).

Despite these impediments, Turkey has not only provided refuge to those fleeing the Syrian turmoil but has made all aspects of the healthcare system accessible to those in need, free of cost. On further introspection into the situation of Syrian refugees and the utilization of RT, there is another important aspect that should not be overlooked. In this analysis we found that even though only a small proportion of Syrian refugee patients with cancer received RT due to the reasons we discussed above, a significant 
number of these patients were non-compliant with multiple scheduled RT sessions. Patient noncompliance is a major setback which eventually hinders the possibility of achieving cancer remission, increasing patient morbidity and mortality. Certain studies have shown that the chances of increase of local recurrence with treatment interruption is almost $2 \%$ per day (25). Tumor repopulation, which is an accelerated growth in malignant tissue after treatment with radiation has been initiated, has been deemed as an integral factor in causing this cancer remission (26). In a retrospective analysis done to ascertain the survival in patients with head and neck carcinoma, any interruption in treatment for more than two weeks was found to be a strong, statistically significant determinant of tumor persistence (27). Apart from its obvious effects on cancer treatment, non-compliance also leads to other complications. In a study conducted in the United States, a ripple-like effect was observed, in which non-compliant patients, by missing their scheduled treatments, indirectly caused delay in treatments of other patients by occupying slots on linear accelerator machines. It was also noted that non-compliance ultimately led to a failure to adhere to follow-up evaluations and other interventions crucial to cancer management (28).

The noncompliance rates vary globally owing to various factors influencing treatment adherence across different nations. In a New York-based clinical investigation involving 1227 patients with various malignancies, Ohri et al concluded that around $20 \%$ of the study patients were non-compliant (29). In another study conducted in a tertiary care center in India, Gupta et a/ demonstrated a non-compliance rate of almost 13\% in 203 cancer patients (30). As per our analysis of the 1010 refugee cancer patients in Turkey that were able to get treated with RT, almost $20 \%$ of them were non-compliant.

There are several factors which can eventually result in non-compliance to radiotherapy and these have been extensively researched in various studies. Significant correlations between non-compliance and low socioeconomic status (SES) have been identified by multiple researchers, with patients belonging to a lower SES group having higher rates of non-compliance $(31,32)$. Another important predictor that has been reviewed is the duration of treatment course. Longer treatment courses have been linked to a greater percentage of patients with non -adherence (33). In rural and suburban populations, the distance required to travel to avail RT services has also been implicated in leading to non-compliance. Patients living farther away from the treatment centers were shown to be more likely to forego RT $(34,35)$. Older age groups have been associated with increased rates of non-compliance. Sharma et al demonstrated in their study of 47 elderly patients with head and neck cancer, that nearly one-third of the study group were not compliant with treatment (36).

As being refugees in an unfamiliar land places them in dire and blindsiding circumstances, they are posed with an additional set of elements that lead to non-compliance when compared with the general population. We have set out to analyze these factors in further detail. Language and cultural barriers play a major role as this hinders communication between refugees and the native healthcare workers (37). Refugees are also faced with competing priorities that include availing basic accommodation, security, hygiene, nutrition and education which take precedence over their need for cancer treatment (38). Noncompliance factors that were extracted specifically in our study were concurrent chemoradiation and living in refugee camps. Some refugees who are financially capable, seek to find their own homes to rent, 
but many who do not have this luxury are provided temporary refugee camps to stay in on arrival.

Patients who have been living in refugee camps when compared to homes are faced with a harsher living environment, contributing to their non-compliance to RT.

Turkey has stood as a beacon of hope to millions of refugees by aiding them in not only providing a home away from their homeland in times of need, but also in allowing these new immigrants access to the same basic human rights as their native citizens. The Turkish government has taken multiple steps to overcome the challenges faced by the Syrian refugees in making use of its healthcare facilities. Provision of translators to overcome the language barriers and appointment of sufficient qualified medical professionals has helped refugees immensely. Above all, healthcare is also provided free of cost, whether it is at the primary, secondary or tertiary levels, with means to alleviate their medical predicaments and ease their transition into the new society (39). Although Turkey has played a crucial role in aiding those escaping the Syrian war, there is still a disparity between what refugees need and what they are granted. A multidisciplinary plan can be taken to address these affairs but, as the well-being of refugees is an international affair, it needs to have a global amalgamation of efforts to produce visible results.

Organizations such as the United Nations (UN), the European Union (EU) and World Health Organization (WHO) can align their efforts with an even greater focus to attempt to alleviate this situation (40). Effective implementation of services should also be ensured with an emphasis on accountability. Measures on a smaller scale can be taken by providing refugees with local working opportunities along with taking the time to teaching them the local dialect, to help them ease integration into the new society. Further studies also need to be done to fathom the finer nuances that refugees deal with on a daily basis as this information can prove invaluable in providing a possible solution to this complex situation. It is imperative that borders do not become barriers in providing optimal radiotherapy for these inconvenienced individuals, regardless of the geopolitical reality.

\section{Abbreviations}

Cl: Confidence Interval

CTCAE: Common Terminology Criteria for Adverse Events

EU: European Union

OR: Odds Ratio

RT: Radiation therapy

SES: Socioeconomic Status

UN: United Nations

WHO: World Health Organization 


\section{Declarations}

Ethical Approval and Consent to participate: This study was approved by the Institutional Review Board of Marmara University Pendik Research and Education Hospital (IRB 09.2019.615) according to the ethical standards laid down in the Declaration of Helsinki.

Consent for publication: All the authors have approved the manuscript and agree with submission to your journal.

Availability of supporting data: All data analyzed during this study are available from the corresponding author on reasonable request.

Competing interests: The authors declare that they have no competing interests.

Funding: This work was supported by ASTRO/ARRO Global Health Scholar Program

Authors' contributions: MS, MFE, SM, NO, BH, BA contributed to the conception and design of the study and critical review of the manuscript. AK, SOK, OD, FC, IB, ODO, GAO, CE, FT, NK, TK, BCB, SS, MA participated in data acquisition. MS, SSK, MFE, SM drafted the manuscript and was responsible for statistical considerations. All authors read and approved the final manuscript.

Acknowledgements: Not applicable

\section{References}

1. Fine S. Liaisons, labelling and laws: International Organization for Migration bordercratic interventions in Turkey. Journal of Ethnic and Migration Studies. 2018;44(10):1743-55.

2. Ekmekci PE. Syrian Refugees, Health and Migration Legislation in Turkey. J Immigr Minor Health. 2017;19(6):1434-41.

3. Ozcurumez S. Lessons from Turkey: Syrians under Temporary Protection, Health Services and NGOs: Saime Ozcurumez. European Journal of Public Health. 2017;27(suppl_3).

4. Alemi Q, Stempel C, Koga PM, Smith V, Danis D, Baek K, et al. Determinants of Health Care Services Utilization among First Generation Afghan Migrants in Istanbul. Int J Environ Res Public Health. 2017;14(2):201.

5. Yazgan P, Eroglu Utku D, Sirkeci I. Editorial: Syrian crisis and migration. Migration Letters. 2015;12:181-92.

6. Bhugra D, Becker MA. Migration, cultural bereavement and cultural identity. World Psychiatry. 2005;4(1):18-24.

7. Cantekin D. Syrian Refugees Living on the Edge: Policy and Practice Implications for Mental Health and Psychosocial Wellbeing. International Migration. 2019;57(2):200-20. 
8. Özmert EN, Derman O, Bideci A, Okumuş N, Boduroğlu K, Bakkaloğlu S, et al. Syrian Children in Turkey: A Model of Action for National Pediatric Societies. Pediatrics. 2019;143(2):e20180539.

9. Connolly MA, Gayer M, Ryan MJ, Salama P, Spiegel P, Heymann DL. Communicable diseases in complex emergencies: impact and challenges. Lancet. 2004;364(9449):1974-83.

10. Slama S, Kim HJ, Roglic G, Boulle P, Hering H, Varghese $C$, et al. Care of non-communicable diseases in emergencies. Lancet. 2017;389(10066):326-30.

11. Ruby A, Knight A, Perel P, Blanchet K, Roberts B. The Effectiveness of Interventions for NonCommunicable Diseases in Humanitarian Crises: A Systematic Review. PLoS One. 2015;10(9):e0138303.

12. United Nations High Commissioner for Refugees Turkey: Syrian Refugee Camps and Provincial Breakdown of Syrian Refugees Registered in South East Turkey.[Available from: https://data2.unhcr.org/en/documents/details/90390.

13. Borras JM, Lievens Y, Grau C. The need for radiotherapy in Europe in 2020: Not only data but also a cancer plan. Acta Oncol. 2015;54(9):1268-74.

14. Celis JE, Pavalkis D. A mission-oriented approach to cancer in Europe: a joint mission/vision 2030. Mol Oncol. 2017;11(12):1661-72.

15. Atun R, Jaffray DA, Barton MB, Bray F, Baumann M, Vikram B, et al. Expanding global access to radiotherapy. Lancet Oncol. 2015;16(10):1153-86.

16. Defourny N, Perrier L, Borras JM, Coffey M, Corral J, Hoozée S, et al. National costs and resource requirements of external beam radiotherapy: A time-driven activity-based costing model from the ESTRO-HERO project. Radiother Oncol. 2019;138:187-94.

17. Datta NR, Samiei M, Bodis S. Radiotherapy infrastructure and human resources in Europe - Present status and its implications for 2020. European Journal of Cancer. 2014;50(15):2735-43.

18. Zubizarreta EH, Fidarova E, Healy B, Rosenblatt E. Need for radiotherapy in low and middle income countries - the silent crisis continues. Clin Oncol (R Coll Radiol). 2015;27(2):107-14.

19. Grover S, Xu MJ, Yeager A, Rosman L, Groen RS, Chackungal S, et al. A systematic review of radiotherapy capacity in low- and middle-income countries. Front Oncol. 2014;4:380.

20. Rosenblatt E, Izewska J, Anacak Y, Pynda Y, Scalliet P, Boniol M, et al. Radiotherapy capacity in European countries: an analysis of the Directory of Radiotherapy Centres (DIRAC) database. Lancet Oncol. 2013;14(2):e79-86.

21. Dincer M, Kuter S. One hundred years of radiotherapy in Turkey. Lancet Oncol. 2001;2(10):631-3.

22. Bakkal Temi Y, Murat Sedef A, Gokcay S, Coskun H, Oskeroglu Kaplan S, Ozkul O, et al. A study on basic demographic and disease characteristics of cancer-diagnosed Syrian refugees treated in the border city of Turkey, Sanliurfa; a hospital-based retrospective case series study. J BUON. 2017;22(6):1591-4.

23. Kebudi R, Bayram I, Yagci-Kupeli B, Kupeli S, Sezgin G, Pekpak E, et al. Refugee children with cancer in Turkey. Lancet Oncol. 2016;17(7):865-7. 
24. Mansour A, Al-Omari A, Sultan I. Burden of Cancer Among Syrian Refugees in Jordan. J Glob Oncol. 2018;4:1-6.

25. Bese NS, Hendry J, Jeremic B. Effects of prolongation of overall treatment time due to unplanned interruptions during radiotherapy of different tumor sites and practical methods for compensation. Int J Radiat Oncol Biol Phys. 2007;68(3):654-61.

26. Yang J, Yue JB, Liu J, Yu JM. Repopulation of tumor cells during fractionated radiotherapy and detection methods (Review). Oncol Lett. 2014;7(6):1755-60.

27. Patel UA, Patadia MO, Holloway N, Rosen F. Poor radiotherapy compliance predicts persistent regional disease in advanced head/neck cancer. Laryngoscope. 2009;119(3):528-33.

28. Ohri N, Rapkin BD, Guha D, Haynes-Lewis H, Guha C, Kalnicki S, et al. Predictors of radiation therapy noncompliance in an urban academic cancer center. Int J Radiat Oncol Biol Phys. 2015;91(1):232-8.

29. Ohri N, Rapkin BD, Guha C, Kalnicki S, Garg M. Radiation Therapy Noncompliance and Clinical Outcomes in an Urban Academic Cancer Center. Int J Radiat Oncol Biol Phys. 2016;95(2):563-70.

30. Gupta S, Rastogi K, Bhatnagar AR, Singh D, Gupta K, Choudhary AS. Compliance to radiotherapy: A tertiary care center experience. Indian J Cancer. 2018;55(2):166-9.

31. Hsieh MC, Velasco C, Wu XC, Pareti LA, Andrews PA, Chen VW. Influence of socioeconomic status and hospital type on disparities of lymph node evaluation in colon cancer patients. Cancer. 2012;118(6):1675-83.

32. Visser BC, Ma Y, Zak Y, Poultsides GA, Norton JA, Rhoads KF. Failure to comply with NCCN guidelines for the management of pancreatic cancer compromises outcomes. HPB (Oxford). 2012;14(8):539-47.

33. Whelan TJ, Pignol JP, Levine MN, Julian JA, MacKenzie R, Parpia S, et al. Long-term results of hypofractionated radiation therapy for breast cancer. N Engl J Med. 2010;362(6):513-20.

34. Meden T, St John-Larkin C, Hermes D, Sommerschield S. MSJAMA. Relationship between travel distance and utilization of breast cancer treatment in rural northern Michigan. Jama. 2002;287(1):111.

35. Pandey KC, Revannasiddaiah S, Pant NK. Evaluation of Factors in Relation with the Non-Compliance to Curative Intent Radiotherapy among Patients of Head and Neck Carcinoma: A Study from the Kumaon Region of India. Indian J Palliat Care. 2015;21(1):21-6.

36. Sharma A, Madan R, Kumar R, Sagar P, Kamal VK, Thakar A, et al. Compliance to therapy-elderly head and neck carcinoma patients. Can Geriatr J. 2014;17(3):83-7.

37. Smith J. Cancer care for refugees. Lancet Oncol. 2014;15(9):e363-4.

38. Spiegel P, Khalifa A, Mateen FJ. Cancer in refugees in Jordan and Syria between 2009 and 2012: challenges and the way forward in humanitarian emergencies. Lancet Oncol. 2014;15(7):e290-7.

39. Assi R, Özger-Illhan S, Illhan MN. Health needs and access to health care: the case of Syrian refugees in Turkey. Public Health. 2019;172:146-52.

40. Marzouk M, Kelley M, Fadhil I, Slama S, Longuere KS, Ariana P, et al. "If I have a cancer, it is not my fault I am a refugee": A qualitative study with expert stakeholders on cancer care management for 
Syrian refugees in Jordan. PLoS One. 2019;14(9):e0222496.

\section{Tables}




\begin{tabular}{|c|c|}
\hline \multicolumn{2}{|l|}{ Age } \\
\hline Median (range) & $49(19-94)$ \\
\hline \multicolumn{2}{|l|}{ Gender } \\
\hline Male & $479(47)$ \\
\hline Female & $531(53)$ \\
\hline History of Smoking & $364(36)$ \\
\hline Family history of cancer & $85(8)$ \\
\hline \multicolumn{2}{|l|}{ Residence } \\
\hline Refugee Camp & $442(44)$ \\
\hline House & $568(56)$ \\
\hline \multicolumn{2}{|l|}{ Diagnosis } \\
\hline Breast cancer & $303(30)$ \\
\hline Lung cancer & $137(14)$ \\
\hline CNS cancer & $128(13)$ \\
\hline Head and neck cancer & $110(11)$ \\
\hline Gl cancer & $101(10)$ \\
\hline Prostate cancer & $69(7)$ \\
\hline Gyn cancer & $64(6)$ \\
\hline Others & $98(9)$ \\
\hline \multicolumn{2}{|l|}{ Stage } \\
\hline HII & $202(20)$ \\
\hline III-IV & $687(68)$ \\
\hline Concurrent chemoradiotherapy & $264(26)$ \\
\hline Noncompliance & $205(20)$ \\
\hline Grade 3-4 acute toxicity & $139(14)$ \\
\hline \multicolumn{2}{|l|}{ Radiation therapy fractions } \\
\hline Mean (SD) & $19.8(9.5)$ \\
\hline Follow-up (mo) & \\
\hline
\end{tabular}


Values are number (percentage) unless otherwise noted

\begin{tabular}{|c|c|c|}
\hline Characteristic & Noncompliance rate, $\mathrm{n}(\%)$ & $P$ \\
\hline Gender & & 0.903 \\
\hline Male & $98 / 479(21)$ & \\
\hline Female & $107 / 531(20)$ & \\
\hline History of Smoking & $73 / 364(20)$ & 0.886 \\
\hline Family history of cancer & 10/85 (12) & 0.041 \\
\hline Residence & & $<.001$ \\
\hline Refugee Camp & $146 / 442(33)$ & \\
\hline House & $59 / 568(10)$ & \\
\hline Diagnosis & & 0.141 \\
\hline Breast cancer & 65/303 (22) & \\
\hline Lung cancer & 24/137 (18) & \\
\hline CNS cancer & $25 / 128(20)$ & \\
\hline Head and neck cancer & $25 / 110(23)$ & \\
\hline Gl cancer & 15/101 (15) & \\
\hline Prostate cancer & $16 / 69(23)$ & \\
\hline Gyn cancer & $7 / 64(11)$ & \\
\hline Others & $28 / 98(28)$ & \\
\hline Stage & & 0.192 \\
\hline$|-| \mid$ & $46 / 202(23)$ & \\
\hline III-IV & 128/687 (19) & \\
\hline Concurrent chemoradiotherapy & $62 / 264(24)$ & 0.134 \\
\hline Grade 3-4 acute toxicity & $20 / 139(14)$ & 0.062 \\
\hline
\end{tabular}


Table 3. Bivariate and multivariate logistic regression results for associations with patient noncompliance

\begin{tabular}{|c|c|c|c|c|}
\hline & Univariate models & & Multivariate model & \\
\hline Characteristic & $\begin{array}{l}\text { Unadjusted OR (95\% } \\
\mathrm{Cl})\end{array}$ & $\mathrm{P}$ & Adjusted OR (95\% Cl) & $\mathrm{P}$ \\
\hline Age & $1.02(0.92-1.01)$ & 0.703 & $1.00(0.99-1.01)$ & 0.988 \\
\hline \multicolumn{5}{|l|}{ Gender } \\
\hline Male & Reference & & Reference & \\
\hline Female & $0.98(0.72-1.33)$ & 0.903 & $1.11(0.78-1.59)$ & 0.553 \\
\hline \multicolumn{5}{|l|}{ Residence } \\
\hline House & Reference & & Reference & \\
\hline Refugee camp & $4.26(3.05-5.95)$ & $<.001$ & $3.62(2.53-5.19)$ & $<.001$ \\
\hline \multicolumn{5}{|l|}{ Stage } \\
\hline $\mathrm{I}-\mathrm{II}$ & Reference & & Reference & \\
\hline III-IV & $0.78(0.53-1.14)$ & 0.193 & $0.76(0.50-1.13)$ & 0.18 \\
\hline \multicolumn{5}{|l|}{$\begin{array}{l}\text { Concurrent } \\
\text { chemoradiotherapy }\end{array}$} \\
\hline No & Reference & & Reference & \\
\hline Yes & $1.29(0.92-1.82)$ & 0.135 & $1.61(1.06-2.46)$ & 0.023 \\
\hline \multicolumn{5}{|l|}{ Acute toxicity } \\
\hline Grade $\leq 2$ & Reference & & Reference & \\
\hline Grade $\geq 3$ & $0.62(0.38-1.03)$ & 0.064 & $0.79(0.45-1.37)$ & 0.399 \\
\hline Radiation therapy fractions & $1.00(0.96-1.02)$ & 0.933 & $0.99(0.72-1.01)$ & 0.467 \\
\hline
\end{tabular}

